\title{
PENERAPAN ABSENSI ONLINE BERBASIS ANDROID PADA PENINGKATAN KEDISIPLINAN DAN KINERJA GURU PEGAWAI NEGERI SIPIL PADA BIDANG PAI
}

\author{
Yani Mulyani \\ Gugus 3 Ahmad Yani, Sindangwangi, Majalengka \\ yanikenzasetiawan@gmail.com
}

\begin{abstract}
This research contains field research on a case study on the application of android-based online attendance on PAI civil servant teachers as human resources who are the spearbead of educational success through discipline and performance with the enactment of android-based online attendance. This study aims to (1) Explain how the application of Android-based online attendance in Gugus 3 Ahmad Yani; (2) Describe how the discipline and performance of PNS teachers in the PAI field in Gugus 3 Abmad Yani Sindangwangi District Majalengka Regency; (3) Describe the application of android-based online attendance in improving the discipline and performance of PAI teachers in the PAI field in Gugus 3 Abmad Yani, Sindangwangi District, Majalengka Regency. In this study, the authors used a qualitative approach. By using a phenomenological case study research model. The conclusion of this study is the android-based online attendance is a list of attendance using linuxbased android smart phones as part of technological advances that make it easier to discipline the civil servant teacher in the PAI trial. Even though it is still a pros and cons because the application is not yet perfect, most of buman resources are not ready with technological advancements, economic problems and other personal problems of civil servants.
\end{abstract}

Keywords: online attendance, android, discipline, teacher performance

\section{ABSTRAK}

Penelitian ini berisi penelitian lapangan tentang studi kasus penerapan absensi online berbasis android pada guru Pegawai Negeri Sipil bidang PAI sebagai sumber daya manusia yang menjadi ujung tombak keberhasilan pendidikan melalui pendisiplinan dan kinerjanya dengan diberlakukannya absensi online berbasis android. Penelitian ini bertujuan untuk (1) Menjelaskan bagaimana penerapan absensi online berbasis android di Gugus 3 Ahmad yani Kabupaten; (2) Menggambarkan bagaimana kedisiplinan dan kinerja guru PNS pada bidang PAI di Gugus 3 Ahmad Yani Kecamatan Sindangwangi Kabupaten Majalengka; (3) Mendeskripsikan penerapan absensi online berbasis android dalam peningkatan kedisiplinan dan kinerja guru PNS bidang PAI di Gugus 3 Ahmad Yani Kecamatan Sindanggwangi Kabupate Majalengka. Dalam penelitian ini, penulis menggunakan pendekatan kualitatif. Dengan menggunakan model penelitian studi kasus fenomenologi. Kesimpulan dari penelitian ini adalah absensi online berbasis android merupakan daftar kehadiran dengan menggunakan ponsel pintar android yang berbasis linux sebagai bagian dari kemajuan teknologi yang mempermudah sekaligus mendisiplinkan guru Pegawai Negeri Sipil dalam dalam nidang PAI. Walaupun masih menjadi pro kontra karena aplikasi yang belum sempurna, Sumber Daya Manusia yang belum siap dengan kemajuan teknologi, masalah ekonomi dan pribadi pegawai negeri sipil lainnya.

Kata kunci : Absensi Online, Android, Kedisiplinan, Kinerja Guru

Submitted Apr 29, 2020 | Revised Jun 19, 2020 | Accepted Jun 25, 2020

\section{Pendahuluan}

Pengaruh perkembangan Teknologi Informasi sekarang ini sudah menjangkau ke semua bidang pendidikan, kebutuhan informasi yang akurat, tepat dan cepat dalam menyajikan data 
yang sangat lengkap merupakan salah satu tujuan penting. Untuk ini smartphone berperan aktif dalam segala bidang dan akan mempermudah pekerjaan manusia. Informasi sangat penting sekali bagi semua orang, dengan adanya informasi akan terjadi pula timbal balik pada kemajuan baik di segala bidang. Dari adanya sebuah kemajuan tersebut maka akan terjadi sebuah perubahan, dan perubahan akan terjadi jika adanya informasi yang di buat dan dengan adanya sebuah informasi maka akan dikembangkan lagi sebuah penemuan baru. Saat ini dunia sedang mengalami proses revolusi penerapan teknologi komputer yang disebut dengan digitalisasi.

Pemanfaatan teknologi smartphone yang kemudian sangat pesat perkembangannya. Keunggulan dari smartphone dengan sistem operasi android memungkinkan pengguna untuk memasang banyak aplikasi yang dapat menunjang pekerjaan keseharian mereka. Hal inilah yang menyebabkan pengguna smartphone di Indonesia mencapai sekitar 55 juta pengguna yang menempatkan Indonesia sebagai pengguna ketiga terbanyak setelah China dan India dalam cakupan Asia Pasifik(Jose, 2015).

Pemanfaatan sistem teknologi informasi yang semakin maju dapat mengatasi hal-hal yang tidak diinginkan diatas dengan adanya sistem absensi yang digitalisasi dapat memberikan pencapain kinerja pada sekolah tersebut.Android adalah sistem operasi untuk smartphone. Android menyediakan platform terbuka bagi para pengembang untuk menciptakan aplikasi mereka sendiri yang telah digunakan oleh bermacam peranti bergerak. Salah satu perangkat mobile yang paling pesat adalah Handphone dimana Perkembangan teknologi semakin pesat dan cepat, khususnya teknologi informasi dan komunikasi

Penelitian ini pada dasarnya terkait dengan persoalan peningkatan mutu sumber daya manusia di lingkungan pemerintahan Kabupaten Majalengka yang berfokus pada Guru Pegawai Negeri Sipil (PNS) pada bidang PAI di lingkungan pendidikan Gugus 3 Ahmad Yani Kecamatan Sindangwangi melalui implementasi kebijakan absensi online berbasis android yang mulai diterapkan tahun 2019. Sumber daya manusia merupakan faktor sentral dalam suatu organisasi. Apapun bentuk serta tujuannya, organisasi dibuat berdasarkan berbagai visi untuk kepentingan manusia dan dalam pelaksanaan misinya dikelola dan diurus oleh manusia. Jadi, manusia merupakan faktor strategis dalam semua kegiatan institusi/organisasi. Manajemen sumber daya manusia (buman resources management) adalah suatu kegiatan pengelolaan yang meliputi pendayagunaan, pengembangan, penilaian, pemberian balas jasa bagi manusia sebagai individu anggota organisasi atau instansi. Manajemen sumber daya manusia melibatkan semua praktek manajemen yang dapat mempengaruhi secara langsug terhadap organisasi (Simamora, 1999). Dalam hal pengembangan SDM, pendidikan memiliki nilai strategis dan mempunyai peran penting sebagai suatu investasi di masa depan. Menurut Hasibuan, upaya pengembangan sumber daya manusia ini merupakan kegiatan yang harus dilakukan oleh setiap organisasi agar kemampua serta sikap sumber daya manusia semakin meningkat sesuai dengan tuntutanpekerjaan dan kebutuhan instansi (Hasibuan, 2009). Karena secara teoretis, pendidikan adalah dasar dari pertumbuhan ekonomi, dasar dari perkembangan sains dan teknologi, mengurangi kemiskinan dan ketimpangan dalam pendapatan, dan peningkatan kualitas peradaban manusia pada umumnya (Vaizey, 1980). 


\section{Metode Penelitian}

Bertitik tolak dari pemikiran dan permasalahan di atas, metodologi yang digunakan dalam penelitian ini adalah penelitian kualitatif, yaitu strategi dan teknik penelitian yang digunakan untuk memahami masyarakat dengan sebanyak mungin mengumpulkan fakta yang mendalam, data disajikan dalam bentuk verbal, bukan dalam bentuk angka. Pendekatan kualitatif memiliki karakteristik alami sebagai sumber data langsung, deskriptif, proses lebih dipentingkan dari pada hasil, analisis dalam penelitian kualitatif cenderung dilakukan secara analisa induktif dan makna merupakan hal yang esensial (Moleong, 2002). Penilitian kualitatif bersifat subyektif dan refleksif. Dalam penelitian kualitatif tidak digunakan instrument standar, tetapi penelitian berperan sebagai instrument (Sukmadinata, 2013). Pengamatan dapat dilakukan tanpa dan dengan partisipasi peneliti. Mengamati sambil berpartisipasi dapat menghasilkan data yang lebih banyak, lebih mendalam dan lebih terperinci. Agar menjadi partisipan dan sekaligus pengamat, peneliti hendaknya turut serta dalam berbagai peristiwa dan kegiatan, tapi ada kalanya peneliti hanya dapat menjadi pengamat tanpa berperan sebagai partisipan (Nasution, 1988).

Penelitian ini dilakukan pada guru PAI di Gugus 3 Ahmad Yani Kecamatan Sindangwangi Kabupate Majalengka. Penelitian ini mendeskripsikan tentang peranan kepala sekolah dalam upaya meningkatkan kualitas tenaga pendidik. Berdasarkan hasil penelitian yang telah dilaksanakan, strategi kepala sekolah di Gugus 3 Ahmad Yani Kecamatan Sindangwangi dalam upaya meningkatkan kualitas tenaga pendidik adalah dengan melakukan strategi kolaboratif.

\section{Hasil dan Pembahasan}

Dalam melakukan penelitian, penulis melakukan wawancara langsung terhadap Pegawai Negeri Sipil bidang PAI, ketua gugus 3 Ahmad Yani, Staff bidang GTK Dinas Pendidikan Kabupaten Majalengka, dan beberapa Kepala Sekolah di Gugus 3 Ahmad Yani.

Setelah penerapan absensi online ini mulai diberlakukan di awal tahun ajaran baru 20192020 peneliti mengamati semua Guru PNS sudah berada di sekolah sebelum pukul 07.00. Mereka menjadi lebih banyak waktu untuk mempersiapkan pembelajaran sebelum masuk kelas pada pukul 07.30. Menurut pengamatan peneliti sebagai partisipan aktif, pada awalnya beberapa guru datang pukul 08.30 atau lebih dan langsung masuk ke dalam kelas tanpa persiapan dan perencanaan. Padahal dalam Permendikbud Nomor 81A Tahun 2013 tentang implementasi kurikulum 2013 khususnya pedoman umum pembelajaran mengatur bahwa RPP wajib disusun oleh guru sebelum guru masuk kelas. Karena dengan adanya perencanaan guru telah menetapkan segala keperluan serta metode yang harus diterapkan ketika melaksanakan pembelajaran termasuk dapat mengelolah waktu secara efisien. Dengan demikian memungkinkan tujuan pembelajaran mudah dicapai. Namun setelah penerapan absensi online ini berjalan, kedisiplinan Guru PNS dalam hal ini disipin waktu otomatis meningkat.

Tujuan dari penggunaan absensi online berbasis android sebagai mesin absensi yaitu:

a. Meningkatkan produktivitas pegawai terhadap organisasi yang berawal dari kedisiplinan atas kehadiran di tempat kerja.

b. Memberikan kemudahan dan kenyamanan dalam proses absensi pada kepegawaian dan dapat meningkatkan efisiensi waktu dalam pembuatan laporan absensi bagi unit kerja, khususnya bagian kepegaiwan. 
c. Meningkatkan sistem paperless pada organisasi yang dimulai dengan sistem absensi sidik jari yang dapat mengurangi biaya dalam materi maupun operasional

d. Memberikan informasi yang selengkap-lengkapnya kepada pimpinan dan bagian kepegawaian yang berhubungan dengan kedisiplinan pegawai berupa absensi kehadiran kerja yang merupakan salah satu syarat kerja serta memberikan informasi loyalitas pegawai yang dapat dijadikan dasar dalam penilaian kinerja.

Aplikasi sistem absensi guru PNS dengan menggunakan android adalah aplikasi absen online pertama yang dirancang oleh pemerintah Kabupaten Majalengka dalam rangka meningkatkan sumber daya manusia yang akan menjadi faktor penunjang bagi kemajuan suatu daerah khususanya dalam bidang pendidikan.

Efektifitas penerapan kebijakan absensi online berbasis android ini berdasarkan data dari informan masih harus terus di upgrade karena setiap saat pemerintah sebagai manajer para pegawai agar terus memantau setiap kebijakan yang mereka terapkan kepada para pegawainya dengan penuh pertimbangan dan harus melalui evaluasi yang berkala. Termasuk kebijakan untuk menerapkan absensi online berbasis android ini harus terus dilakukan perbaikan sesuai dengan kebutuhan dan kemajuan teknologi yang ada.

\section{Kesimpulan}

Absensi online berbasis android merupakan daftar kehadiran pegawai/siswa/guru yang berisi jam datang dan jam pulang dengan menggunakan ponsel pintar android yang merupakan perangkat bergerak pada sistem operasi untuk telepon seluler yang berbasis linux sebagai bagian dari kemajuan teknologi yang dapat mempermudah absensi guru, akses yang sangat mudah dan cepat dengan menggunakan jaringan WLAN dan dapat diakses dimana pun didalam lingkungan kerja PNS.

Penerapan absensi online berbasis android di Gugus 3 Ahmad Yani telah mampu merubah pola kerja PNS pada bidang PAI. Sebagian besar guru PAI disiplin waktu dalam menjalankan kewajibannya. Sebagian kecil guru PAI yang belum dispilinpun bukan karena tidak mau mendisiplinkan diri tetapi karena berbagai hal seperti Guru PAI yang berperan sebagai ibu rumah tangga juga, masalah ekonomi, dan hal manusiawi lainnya yang menyebabkan PNS tersebut kurang disiplin dalam waktu. Pada hakikatnya kedisiplinan akan kembali lagi kepada pribadi masing-masing.

\section{Daftar Pustaka}

Henry Simamora, Manajemen Sumber Daya Manusia, (Yogyakarta: STIE YPKN, 1999).

Malayu S.P Hasibuan. (2009). Manajemen Sumber Daya Manusia (Edisi Revisi; Jakarta: PT. Bumi Aksara.

John Vaizey. (1980). Pendidikan di Dunia Moderen. Jakarta: Gunung Agung Moloeng, L. (2002). Metodologi Penelitian Kualitatif. (Bandung: PT. Remaja Rosda Karya. Nasution, S. (1988). Penelitian Naturalistik Kualitatif. Bandung: Tarsito.

Sukmadinata, Nana Syaodih. (2013). Metode Penelitian Pendidikan. Bandung : PT. Remaja Rosdakarya 